\title{
Pelatihan Pembuatan Blog di Yayasan Yatim, Piatu dan Dhuafa Rumah Harapan, Teluk Jambe Timur Karawang
}

\author{
Surtika Ayumida ${ }^{1}$ \\ Universitas Bina Sarana Informatika, surtika.skm@bsi.ac.id \\ Fransisca Natalia ${ }^{2}$ \\ Universitas Bina Sarana Informatika, fransisca.fia@bsi.ac.id \\ Yuni Siti Nuraeni ${ }^{3}$ \\ Universitas Bina Sarana Informatika, yuni.yns@bsi.ac.id
}

\begin{abstract}
Abstrak
Era modern ini ditentukan oleh pesatnya perkembangan teknologi informasi. Internet telah menjadi salah satu cara alternatif untuk menemukan segala jenis informasi yang dibutuhkan. Manfaat internet sebagai salah satu solusi untuk mengefisienkan berbagai kepentingan yang sudah dirasakan oleh semua orang. Salah satunya melahirkan media baru yang disebut blog. Blog merupakan singkatan dari web log yang berupa bentuk aplikasi web yang berbentuk tulisan-tulisan (yang dimuat berupa posting) pada sebuah halaman web. Situs web seperti ini dapat diakses oleh semua pengguna internet sesuai dengan topik atau bahasan dan tujuan dari para pengguna blog tersebut. Keterbatasan informasi mengenai teknologi informasi di dalam lingkungan Yayasan Yatim Piatu dan Dhuafa pada Rumah Harapan Karawang membuat kami tergerak untuk memberikan satu pemahaman baru terkait teknologi informasi dan perkembangannya. Tujuan program pengabdian masyarakat ini sebagai bentuk nyata dalam penyampaian ilmu kepada masyarakat khususnya peserta didik yang ada di Yayasan Rumah Harapan, dengan memberikan ilmu serta informasi positif supaya nantinya dapat bermanfaat dalam kehidupan bermasyarakat. Metode yang digunakan adalah berupa pelatihan mulai dari pembahasan teori tentang cara memulai membuat website menggunakan blogspot sampai dengan mempraktekan langsung bagaimana merancang, mendesain dan mengaplikasikan blogspot. Hasil yang dicapai yaitu peserta didik dapat membuat website sendiri dengan desain yang menarik untuk keperluan di lingkungan sekolah maupun kebutuhan di lingkungan masyarakat sekitar.
\end{abstract}

Kata Kunci: Pemanfaatan Blog, Pelatihan, Media Pembelajaran

\begin{abstract}
This modern era is determined by the rapid development of information technology. The internet has become an alternative way to find all kinds of information needed. The benefits of the internet as one solution to streamline the various interests that have been felt by everyone. One of them gave birth to new media called blogs. Blog is an abbreviation of web log in the form of a web application in the form of writings (which are loaded in the form of posts) on a web page. Websites like this can be accessed by all internet users according to the topic or discussion and purpose of the users of the blog. The limited information about information technology in the environment of the Yatim Piatu and Dhuafa Foundation at Rumah Harapan Karawang made us moved to provide a new understanding related to information
\end{abstract}


technology and its development. The purpose of this community service program as a tangible form in the delivery of knowledge to the community, especially students in the Rumah Harapan Foundation, by providing knowledge and positive information so that later it can be useful in community life. The method used is in the form of training starting from discussing theories on how to start creating a website using blogspot to directly practicing how to design, design and apply blogspot. The results achieved are that students can create their own websites with attractive designs for needs in the school environment and the needs of the surrounding community.

Keywords: Utilization of Blogs, Training, Learning Media.

\section{Pendahuluan}

\section{Latar Belakang}

Kewajiban kepada setiap Perguruan Tinggi sebagaimana dijelaskan dalam Tridharma Perguruan Tinggi adalah Pendidikan, Penelitian, dan Pengabdian Masyarakat. Salah satu kewajiban tersebut Bina Sarana Informatika melaksanakan pengabdian kepada masyarakat, hal ini dilaksanakan berkaitan juga dengan kepedulian setiap lembaga atau institusi yang bergerak dibidang Pendidikan khususnya Pendidikan Tinggi dengan mengikuti perkembangan dan kemajuan teknologi khususnya Indonesia sebagai satu negara yang memiliki potensi sumber daya alam dan manusia yang banyak belum dapat disetarakan dengan negaranegara maju.

Universitas Bina Sarana Informatika yang merupakan salah satu Perguruan Tinggi di Karawang merespon akan kebutuhan sumber daya manusia yang berpotensi bagi Negara yang kita cintai ini, maka dalam rangka tugas salah satu Tri Dharma Perguruan Tinggi, kegiatan Pengabdian kepada Masyarakat ini bertujuan untuk memberikan pelatihan dan workshop pembuatan Blog yang akan diberikan kepada yayasan Yatim Piatu dan Dhuafa Teluk Jambe timur Hal yang melatarbelakangi penulis melakukan pengabdian masyarakat adalah: (1) minimnya pengetahuaan peserta didik di yayasan dalam hal penggunaan komputer, (2) Kurangnya pengetahuan mereka tentang internet, (3) Minimnya pengetahuan mereka tentang manfaat Blog, (4) Kurangnya fasilitas di yayasan. Oleh karena itu tim pengabdian masyarakat tergerak untuk terjun langsung ke masyarakat guna memberikan pengetahuan kepada siswa agar mereka juga dapat mengetahui bagaimana manfaat dan cara membuat Blog.

\section{Kajian Pustaka}

Menurut (Parimita, Eryanto, \& Faslah, 2017) memberikan pernyataan bahwa "Internet juga menawarkan berbagai informasi akademis bagi masyarakat, sehingga tanpa dibatasi ruang dan waktu, kapanpun dapat belajar dan mengkaji berbagai pengetahuan dan informasi." Blog adalah kependekan dari Weblog, istilah yang pertama kali digunakan oleh Jorn Barger pada bulan Desember 1997. Jorn Barger menggunakan istilah Weblog untuk menyebut kelompok website pribadi yang selalu diupdate secara kontinyu dan berisi link-link ke website lain yang mereka anggap menarik disertai dengan komentar-komentar mereka 
sendiri. Secara garis besar, Weblog dapat dirangkum sebagai kumpulan website pribadi yang memungkinkan para pembuatnya menampilkan berbagai jenis isi pada web dengan mudah, seperti karya tulis, kumpulan link internet, dokumen-dokumen (file-file Word, PDF, dll), gambar ataupun multimedia. Para pembuat blog dinamakan Blogger. Melalui Blognya, kepribadian Blogger menjadi mudah dikenali berdasarkan topik apa yang disukai, apa tanggapan terhadap link-link yang di pilih dan isu-isu didalamnya. Oleh karena itu Blog bersifat sangat personal. Perkembangan lain dari Blog yaitu ketika Blog memuat tulisan tentang apa yang seorang Blogger pikirkan, rasakan, hingga apa yang dia lakukan sehari-hari. Blog kemudian juga menjadi Diary Online yang berada di Internet. Satu-satunya hal yang membedakan Blog dari Diary atau Jurnal yang biasa kita miliki adalah bahwa Blog dibuat untuk dibaca orang lain. Blogging, atau dalam pengertian Indonesianya ngeblog dengan merujuk tulisan diatas, merupakan aktifitas memperbaharui blog. Baik mempublish atau menerbitkan postingan terbaru, mereply komentar yang masuk, mempromosikan blog dengan mensubmit ke berbagai direktory, dan yang lainnya. Blogging, atau ngeblog merupakan aktifitas yang menyenangkan. Di antaranya dengan blogging kita bisa menambah ilmu pengetahuan kita tentang dunia maya dan seluk-beluknya, juga bisa menambah teman-teman baru dari berbagai belahan dunia dengan beragam latar belakang. Blog walking merupakan sebuah aktivitas (ketika sedang blogging) mengunjungi blog orang lain. Diantara manfaatnya adalah dengan melakukan blogwalking, kita akan mendapatkan pengetahuan lebih dan memberikan komentar.

Menurut (Permana, 2011) mengatakan bahwa "Website bisa dikatakan sebagai media terpopuler di Internet. Hampir semua pengguna internet selalu memanfaatkan media website, baik untuk mencari ataupun menyediakan informasi di internet. Ketika mengikuti berita terkini di salah satu media online, di saat itulah kita mengakses sebuah website"

Menurut (Hakim, 2019) menyatakan bahwa "Dampak pemasaran online sudah terasa yaitu terjadinya perubahan pola konsumsi masyarakat khususnya untuk konsumsi pakaian dari yang biasanya berbelanja offline di toko, gerai, supermarket atau mall sebagian konsumen beralih ke belanja online melalui web." Menurut (Sanjaya, 2010) mengemukakan bahwa "Banyak pengusaha yang telah memanfaatkan Blog sebagai media penjualan dan promosinya di internet. Pemilihann ini tentunya bukan tanpa alasan. Selain mudah dan familiar dalam penggunaannya, Blogspot juga dapat dimanfaatkan tanpa harus mengeluarkan biaya"

Menurut (Krisianto, 2015) memberikan pengertian bahwa "Blogspot adalah platform yang direkomendasikan, karena fitur-fiturnya cukup mudah digunakan. Selain itu, dengan dukungan mesin pencari google, blog Anda akan lebih mudah ditemukan oleh pengunjung."

(Mulyani, Wibisono, Alawiyah, \& Warnilah, 2019) "Pelatihan merupakan serangkaian aktivitas individu dalam meningkatkan keahlian dan pengetahuan secara sistematis sehingga mampu memiliki kinerja yang profesional di bidangnya" 


\section{Metode}

Metode kegiatan ini adalah berupa pelatihan dan workshop, di mana para peserta didik mempelajari matero teori dan mempraktekan langsung bagaimana merancang, mendesain dan mengaplikasikan blogspot. Dengan tahapan: pemberian informasi dengan powerpoint dan printout yang dibagikan. Metode ini penting untuk menyampaikan informasi-informasi penting berkaitan dengan informasi berinternet secara sehat, teknik penulisan ilmiah dan teknik mendesain blogspot. (2) tanya jawab yang dilaksanakan secara aktif oleh seluruh peserta didik, (3) praktek simulasi membangun blog dan penulisan konten positif yang bernilai ilmiah, (4) Motivasi menciptakan konten positif yang dapat diakses dan dimanfaatkan orang lain. Kegiatan dilaksanakan dalam beberapa hari sesuai dengan jadwal kegiatan yang sudah disepakati.

\section{Hasil dan Pembahasan}

\section{Tema dan Bentuk Kegiatan}

Kegiatan yang dilakukan memiliki tema Pelatihan Pembuatan Blog untuk peserta didik pada yayasan Rumah Harapan.

\section{Tempat dan Waktu Kegiatan}

Kegiatan pengabdian masyarakat bertempat di ruang serbang guna yayasan Rumah Harapan yang berlokasi di Jalan Raya Perumnas Teluk Jambe, Blok G No. 14, Kecamatan Teluk Jambe Timur, Kabupaten Karawang, Provinsi Jawa Barat pada hari Sabtu, 27 April 2019.

\section{Peserta dan Penyelenggara Kegiatan}

Peserta merupakan peserta didik pada yayasan Rumah Harapan Karawang, sedangkan panitia penyelenggara kegiatan merupakan dosen dan mahasiswa Program Studi Sistem Informasi pada Fakultas Teknologi Informasi di Universitas Bina Sarana Informatika yang berjumlah tujuh orang.

\section{Gambaran Proses Kegiatan}

Kegiatan dilaksanakan pada hari Sabtu, 27 April 2019. Kegiatan dimulai dengan pembukaan dan sambutan oleh Ketua Yayasan Rumah Harapan Karawang, Ketua Pelaksana, dan perwakilan dosen selaku perwakilan dari Universitas Bina Sarana Informatika. 
Jurnal Pengabdian Kepada Masyarakat

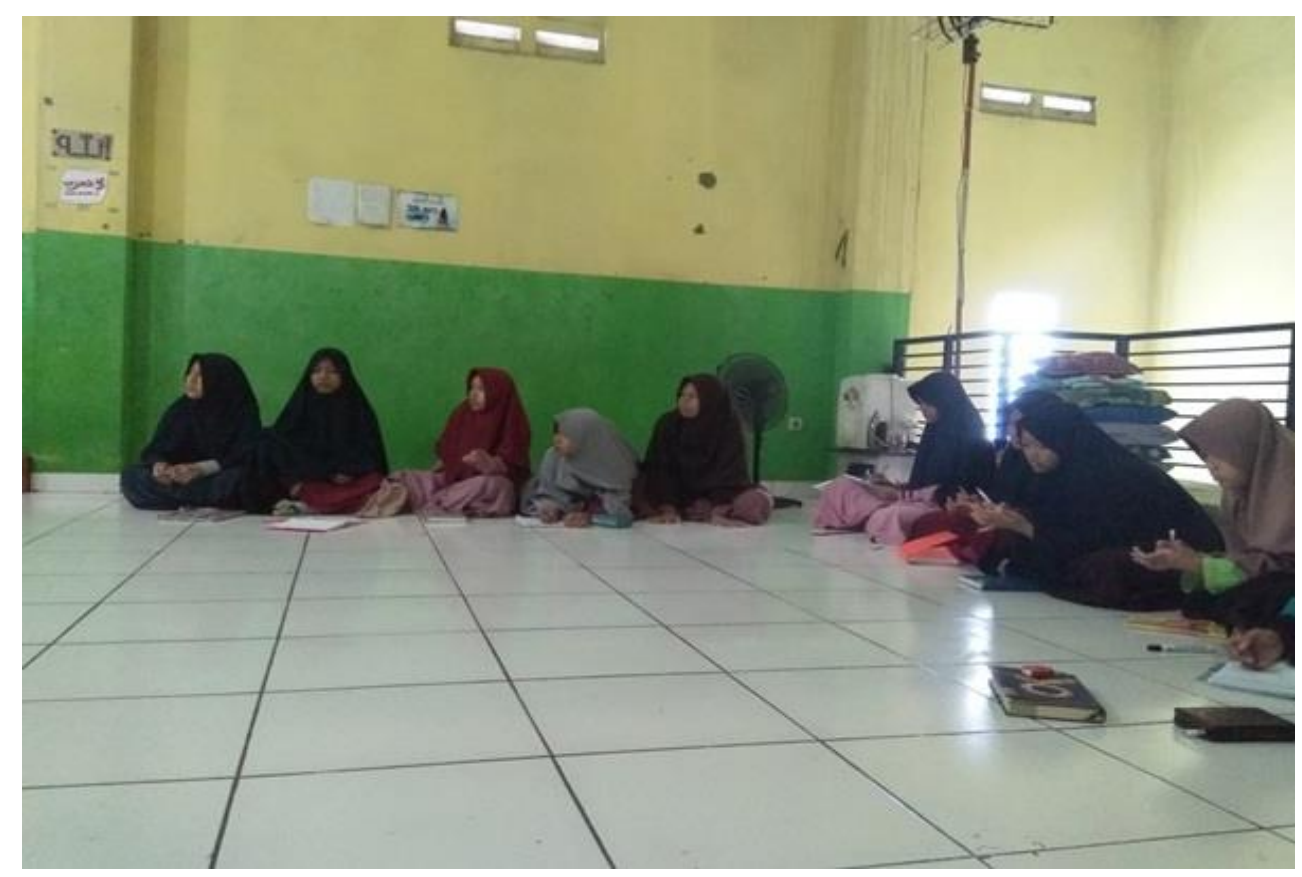

Gambar 1. Foto Saat pemberian materi berupa teori tentang Blog

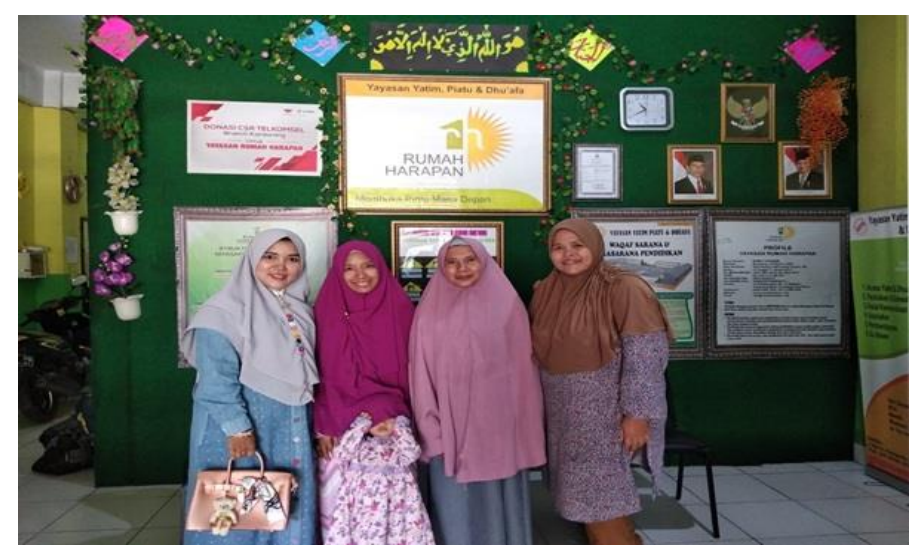

Gambar 2. Foto Bersama Pengurus Yayasan Rumah Harapan

Setelah pembukaan dan sambutan, kegiatan selanjutnya yaitu materi tentang pembuatan blog mulai dari sejarah blog berikut istilah awal blog terbentuk oleh John Barger pada 17 desember 1997, menjelaskan tentang perbedaan antara blog dan website, Apa saja yang dapat ditulis dalam pada blog? , manfaat pembuatan blog, menjelaskan tentang cara mendapatkan pekerjaan dengan menggunakan blog, langkah-langkah ataupun cara-cara mendapatkan tambahan uang dengan menggunakan blog, dan juga mendapatkan penghasilan uang melalui pengunjung. Setelah selesai materi, dilanjutkan dengan makan siang bersama dengan peserta didik, pengurus yayasan, mahasiswa dan dosen. Setelah itu foto bersama dan penutupan dengan doa. 


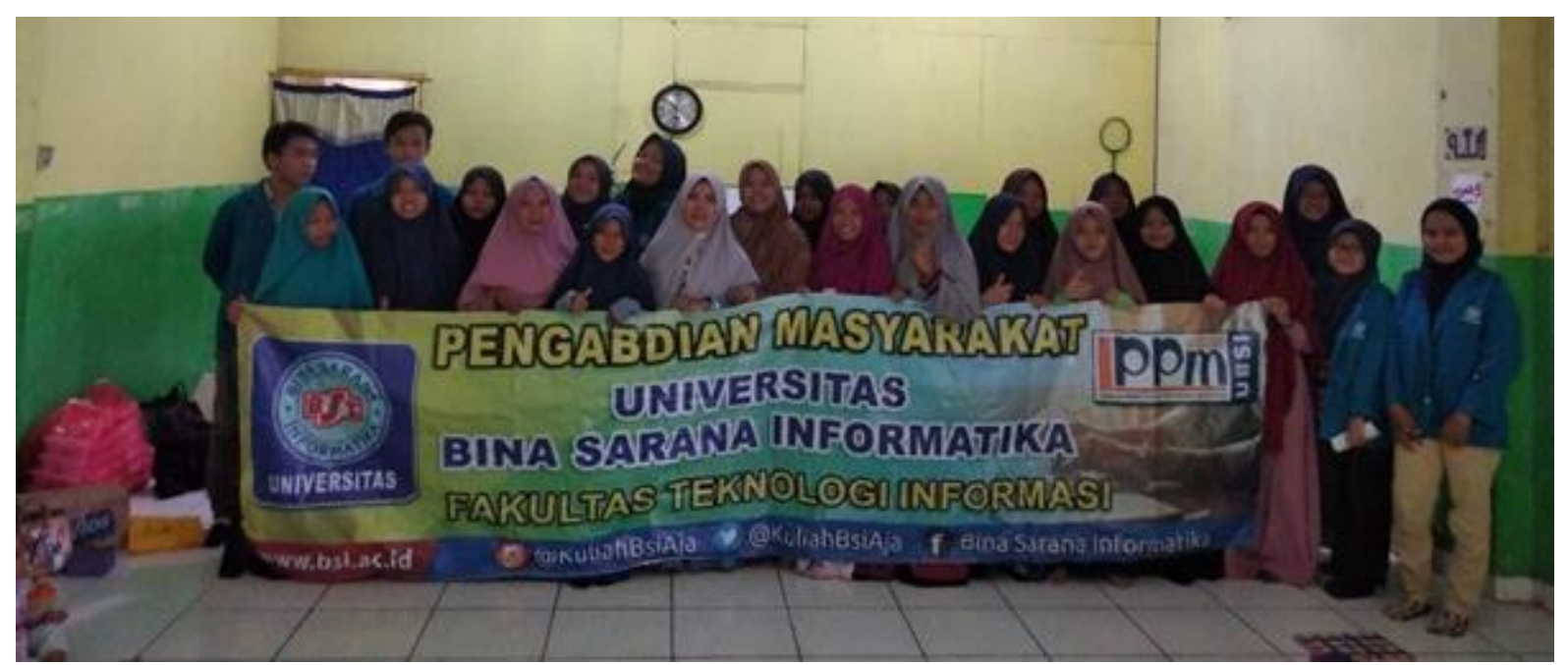

Gambar 3. Foto Bersama keseluruhan

\section{Simpulan dan Rekomendasi}

Pelatihan membuat blog telah dilaksanakan pada bulan April bertempat di Yayasan Rumah Harapan Karawang. Peserta pelatihan adalah para peserta sebanyak 17 orang.

Metode pelatihan dilaksanakan untuk memudahkan pencapaian tujuan sesuai dengan materi pelatihan yang disajikan. Peranan pemanfaatan internet sangatlah penting untuk kehidupan sekarang ini, seperti halnya dalam pemanfaatan blog, maka dari itu blog dapat digunakan dalam media pembelajaran dan juga untuk bisnis. Untuk peserta didik yang ada di dalam naungan yayasan Rumah Harapan Karawang diharapkan dapat membuat, memanfaatkan dan mempergunakan blog dengan sebaik mungkin sehingga dapat bermanfaat. Dalam kegiatan pengabdian masyarakat di yayasan Rumah Harapan Karawang didapat kesimpulan bahwa proses pengabdian kepada masyarakat dapat dilakukan dimanapun bahkan di lingkungan terdekat dan dengan cara paling sederhana sekalipun. Pemahaman bahwa pengabdian harus dilakukan di tempat yang jauh dan terasing justru membuat kita mengabaikan lingkungan terdekat yang sebenarnya juga membutuhkan sentuhan lingkungan terdekat dari lokasi terdekat kampus baik mahasiswa maupun dosen. Dalam proses pengabdian ini dapat diketahui juga bahwa ilmu yang dipelajari selama masa perkuliahan dapat dipraktekkan secara maksimal serta dapat memberikan sudut pandang yang baru dalam kehidupan bermasyarakat.

\section{Daftar Pustaka}

Hakim, L. (2019). Pelatihan Pemasaran Online Berbasis Marketplace Bagi UMKM Dalam Merespon Perubahan Perilaku Konsumen. Loyalitas, Jurnal Pengabdian Kepada Masyarakat, II(1), 74-91. Retrieved from http://www.ejournal. iaida.ac.id/index.php/loyal/article/view/353 
Jurnal Pengabdian Kepada Masyarakat

Krisianto, A. (2015). Jago Blogspot, Pendoman Cepat Jadi Blogger. Jakarta: PT Elex Media Komputindo.

Mulyani, Y. S., Wibisono, T., Alawiyah, T., \& Warnilah, A. I. (2019). Pelatihan Komputer Dasar Untuk Mendukung Proses Kegiatan Belajar Mengajar ( KBM ) Bagi Guru-Guru RA / TPQ / DTA Al-Ishlaah Kota Tasikmalaya. 2(2), 234-240. Retrieved from https://ejournal.bsi.ac.id/ejurnal/index.php/abdimas/article/view/5768

Parimita, W., Eryanto, H., \& Faslah, R. (2017). Pengembangan Perilaku Berinternet Sehat. Jurnal Pemberdayaan Masyarakat Madani (JPMM), 1(1), 33-45.

Permana, L. (2011). Membuat Website Profesional dengan Blogspot Animasi Kartun Dengan Macromedia Flash 8. Jakarta: PT Elex Media Komputindo.

Sanjaya, R. (2010). Toko Online dan Gerai Bisnis dengan Blogspot. Jakarta: PT Elex Media Komputindo. 